\title{
DREAMING UP A NEW GRID: TWO LECTURERS' REFLECTIONS ON CHALLENGING TRADITIONAL NOTIONS OF IDENTITY AND PRIVILEGE IN A SOUTH AFRICAN CLASSROOM
}

\author{
Asanda Ngoasheng \\ Cape Peninsula University of Technology \\ ngoashenga@cput.ac.za
}

\section{Daniela Gachago}

Cape Peninsula University of Technology

Gachagod@cput.ac.za

\section{ABSTRACT}

One of the biggest debates in South Africa is the use and usefulness of apartheid categories when analysing society and societal behaviour. This paper examines the process of learning and unlearning that took place when a political reporting lecturer and an academic staff developer sought to explain racially biased voting in South Africa and its historical origins to students. The autoethnographic method of reflecting on teaching practice is used to explore the tensions and dilemmas that arose when introducing a specific pedagogic interventionthe Privilege Walk-to help students understand privilege as systemic, intersectional and historically rooted. We also discuss our own further development of the walk to allow students to create a new grid based on alternative values and that would affirm difference. Framed by Fraser's participatory parity, critical pedagogy and Massumi's affect theory, we trace our journey in engaging and disrupting identity politics by developing a decolonising pedagogical approach that emphasises post-apartheid identity as fluid and becoming and capitalises on affective and embodied learning in South African classrooms.

Keywords: critical pedagogy; race relations; privilege; intersectionality; socially just pedagogy; participatory parity; identity; identity politics; decolonisation; journalism studies; South Africa

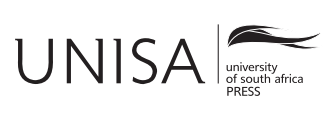

Education as Change

Volume 21 | Number 2 | 2017 | pp. 187-207

www.educationaschange.co.za https://doi.org/10.17159/1947-9417/2017/2479

ISSN 1947-9417 (Online), ISSN 1682-3206 (Print)

(C) The Author(s) 2017 


\section{INTRODUCTION}

The question of identity and its impact on citizenship and notions of belonging (YuvalDavis 2006) - who we are and what makes us so- has occupied the minds of South African academics for many decades (Erasmus 2001; Mangcu 2015; McKaiser 2014; Ndlovu-Gatsheni 2013). South Africa's struggle with identity is more pronounced than other countries' because of its apartheid history (Ndlovu-Gatsheni 2013). Baines (1998, 1) explains further that apartheid "justified separate development policies in terms of primordially-conceived ethnic differences. This had the effect of collapsing individual ethnicities into white and black, us and them." This oversimplified and essentialised characterisation of South African identity as either white or black poses a range of challenges. The emphasis on difference and keeping races apart has made it difficult to develop a multiracial South African identity (Baines 1998). There is little study into the grey areas of apartheid hierarchy such as the differentiated experiences of oppression among black people (i.e. Indian, Coloured and African) and its impact on post-apartheid identities. The white/black binary also does not do justice to the complexities of intersectionality, such as the impact that gender and class have within one race.

The \#RhodesMustFall and \#FeesMustFall student movements of 2015 and 2016 have foregrounded a renewed interest in identity politics, i.e. the tendency to politically associate and organise based on identity, rather than issues or ideology, and the need for decolonisation of the curriculum as part of this identity seeking project. The student protests relied heavily on identity politics - the movement was framed as a black ${ }^{1}$ one in all tertiary institutions in South Africa, and black pain ${ }^{2}$ was centred as well as the black intellectual. The intersectionality of race, gender and sexuality played out in interesting ways as demonstrated in the following two incidents. The complexity of race and class was emphasised by the nature of the participation of white students in the protests, who took on the role of "allies"- supporting a movement led by black students highlighting black experiences of continued oppression in white spaces - using their white privilege ${ }^{3}$ strategically by for example acting as human shields and protecting their black counterparts from police brutality during \#FeesMustFall protests (Sheriff 2015) or setting up support stations, handing out drinks and snacks during occupation of buildings and demonstrations. The intersection of race, sex and gender was demonstrated by the leadership of black feminist women in the movement (Matandela

1 Black as political definition (Biko 1978), includes African, Coloured and Indian South Africans. The term Coloured was introduced during apartheid and refers to those South Africans loosely bound together for historical reasons such as slavery and a combination of oppressive and preferential treatment during apartheid, rather than by common ethnic identity (Erasmus and Pieterse 1999).

2 See Khanya Mtshali's blog post "Rhodes Must Fall: The End of Negotiating Black Pain in PostApartheid South Africa": http://www.forharriet.com/2015/04/rhodes-must-fall-end-of-negotiating. html\#axzz4eigt0Tp9 (accessed August 20, 2017).

3 We will discuss "white privilege" later in the article. 
2015) and the pivotal role that the University of Cape Town's (UCT) Trans Collective 4 played, particularly in the 2015 \#RhodesMustFall protests. The presence of black, often transgender, women in this movement was one example of the shifting of political power (Matandela 2015), although these voices were increasingly marginalised during the 2016 \#FeesMustFall protests. All these factors have renewed the debate around both the importance and the dangers of identity politics. They have also rekindled discussions around the complexities of intersectionality - the recognition that social positions like race, age, social class, ethnicity, culture etc. have an impact on how we experience oppression (Samuels 2008). Yuval-Davis (2006) speaks of intersectionality as the idea that social location must be constructed along multiple axes of difference, such as race, class, gender, and sexuality. These axes of difference are intersectional and overlap often in post-apartheid South Africa.

In this paper we reflect on the process of learning and unlearning that took place when a political reporting lecturer and an academic staff developer sought to decolonise the journalism curriculum by addressing identity politics in South African elections. We will describe the conflicts that emerged in the classroom and discuss the pedagogical interventions we introduced to address these conflicts.

\section{BACKGROUND TO THE STUDY}

The election of 1994 was seen as a watershed moment for South Africa, but much of the perceived unity of the nineties has since been eroded. In The Colour of Our Future (Mangcu 2015) various authors argue that the issue of race did not disappear with the introduction of democracy and a constitution in South Africa, but continues to this day with some South Africans even accepting imposed racial identities for the purposes of resistance. An example of the adoption of forced identity is that of people of colour who self-identify as black as they believe this identity is no longer just a race or colour but testament of their lived experiences of oppression. For the oppressed thus, claiming their identity can be seen as an act of resistance (hooks 1994).

Some aspects of the voting patterns that emerged after the first post-apartheid election surprised analysts. While the fact that most South Africans voted along racial lines was expected given our apartheid history, the voting patterns that emerged from the Coloured community in particular differed as they did not vote for a party that racially represented them (Harvey 2016). In that election and others that followed, Coloured people voted in their majority first for the white dominated former apartheid oppressor, the National Party (NP) and then for the white dominated Democratic Alliance (DA), which won provincial elections in the Western Cape. There are many explanations for these voting patterns but they are often uncritical and essentialist, such as a perceived proximity to whiteness or internalised racism of Coloured people (Erasmus and

See https://www.facebook.com/transfeministcollective/ 
Pieterse 1999). ${ }^{5}$ While there is no space in this paper to provide a lengthy discussion of Coloured identity and political affiliations, this phenomenon, as Erasmus and Pieterse $(1999,184)$ point out, shows that racialised identities have to be seen as "relational, created and recreated through struggle, situational, contradictory, and multiple" and highly dependent on an understanding of their socio-cultural and historical context. In a political reporting class, a conversation around post-apartheid interracial conflict and the voting patterns of Coloured and African people in the Western Cape proved to be the starting point of a difficult conversation about differentiated experiences of oppression during apartheid which this paper reflects on.

Employing an autoethnographic research design (Ellis 2004), which combines writing, story and method to connect the autobiographical and the personal to the cultural, social, and political, we reflect on how we experienced and made sense of the complexities of engaging with privilege and intersectionality and how it played out in the classroom. Autobiographical studies are usually written up in first person narratives, in a variety of forms, such as short stories, poetry or journal entries (Ellis 2004). In autoethnography personal stories enter into dialogue with theory to make meaning of experience; as Ellis notes: "Autobiographical stories really make theory and history come alive" $(2004,24)$. She adds that the "goal is to write meaningfully and evocatively about topics that matter and may make a difference, to include sensory and emotional experiences, and to write from an ethic of care and concern" (46). In this paper our complex experiences, feelings and thoughts as we were teaching in this class are presented in a range of autobiographical reflections and snapshots by the first author and course lecturer and the second author, an academic staff developer.

Decolonising pedagogies aim to recognise the structures of colonisation, while intentionally engaging in practices and processes that disrupt colonial power (IsekeBarnes 2008; Kanu 2011). Iseke-Barnes $(2008,124)$ writes: "One strategy for decolonising is to create a sense of the complexity of colonial oppression and how it is systematically exercised." In our case this complexity became evident when we tried to unpack the fact that Coloured people, while partly made up of descendants of slaveshistorically the most oppressed group - were still placed on a level higher than Africans in the class and race hierarchy developed during apartheid (Harvey 2016). We sought to explain to students how the apartheid government exercised their power across different communities in South Africa and how this hierarchy continues to divide communities today. Our reflections show the importance of revealing social structures impacting students' engagements inside and outside the classroom - a core call of a decolonising pedagogy - but also the challenges when doing so, such as the questions around who learns and at whose cost (Leonardo and Porter 2010).

Difficult knowledge is defined by Britzman $(2000,202)$ as the encounter with traumatic experiences and the coming to terms "with various kinds of trauma, both individual and collective" in the classroom. Engaging with difficult knowledges can be

$5 \quad$ For a detailed discussion see for example Erasmus and Pieterse (1999). 
re-traumatising to already vulnerable students. Zembylas (2014) explains this concept of difficult knowledge further as signifying both representations of social and historical traumas in the curriculum and the learner's encounters with them in the classroom. Engaging with the legacies of apartheid that still impact on students' everyday lives can be classified as difficult knowledge. In particular the responses of students associated with (even relative) privilege, often characterised by defensiveness, can be re-traumatising, invalidating and silencing of other students' experiences. Zembylas $(2013,511)$ explains this defensiveness as the "emotional resistance of those students who feel they are victims themselves (e.g., students who are marginalised at various degrees) [which] entails feelings of indignation, self-pity, and resentment for paying attention to others' suffering." Guilt and the fear of being made responsible for a collective crime are other reasons for students' defensiveness and lack of engagement in difficult knowledges: "fearing that they will be exposed as immoral by refusing to bear any longer a population's collective suffering" (Zembylas 2011, 20).

The dilemmas that we faced in presenting and challenging notions of identity and its effects on politics in South Africa were:

- How do we deal with the differentiated experiences of apartheid between African, Coloured and Indian people without reproducing apartheid categories and identities in the post-apartheid era?

- What dangers do we encounter when we essentialise race and identity when analysing African and Coloured people as both groups represent people of colour?

- How do we move past the defensiveness that usually accompanies engagements with difficult knowledges in diverse classrooms?

- How do we protect the vulnerability of students, especially those who are coming into this knowledge for the first time and have to deal with difficult knowledge in front of their peers?

The paper moves through different theories, with different ontologies, foci and intentions, which helped us make sense of what we saw, sensed and felt in our classroom. Nancy Fraser's participatory parity $(1999,2008,2013)$ was used as a guiding frame. Fraser emphasises the importance of understanding the systemic interrelatedness of redistribution, recognition and representation when working towards socially just societies. In this paper we discuss the opportunities and challenges of identity politics. We use the work of critical pedagogues, such as Peggy McIntosh (1992) and bell hooks $(1994,2000 \mathrm{a}, 2000 \mathrm{~b})$ to discuss the Privilege Walk. The walk is one of the activities introduced into the classroom to allow students an embodied experience of systemic privilege and intersectionality. We also engage with the limitations of such critical pedagogies, in particular around the question of who learns and at whose cost. We then turn to affect theorist Brian Massumi (2002), who helped us to further develop the 
Privilege Walk in an attempt to disrupt current social grids and dream up new grids, new worlds, based on alternative values and views of the world.

\section{REFLECTION 1: SETTING THE SCENE}

Asanda: One of the learning objectives of Political Reporting, the course which I teach, is for students to be able to analyse political events for political writing and reporting. This requires students to understand complex processes like the voting process and the voting patterns of South Africans - nationally but even more in our locale - the Western Cape. The province is the only opposition party-led province in South Africa. This provides a complex set of unique factors that make it distinct from the rest of South Africa. The Western Cape has also been a site of some conflict between African and Coloured population groups which plays itself out before every election and is used by both provincial opposition (the African National Congress-ANC) and the provincial ruling party (the Democratic Alliance-DA). I wanted students to understand this complex set of factors, what the source of the conflict was and how politicians use it. I also wanted them to understand how the conflict in part stems from our complicated history of differentiated experiences of apartheid oppression between black populations from African, Coloured and Indian communities in South Africa.

To achieve this, I gave students an assignment to research the conflict between the African and Coloured population in the Western Cape and produce a multimedia article on it which encompassed interviews as well as their own analysis of the conflict and its impact on the lived experiences of African and Coloured residents of the Western Cape. As part of the assignment I asked each student to reflect and share orally with the class what they found in their research. Most students reported that they did not find any conflict at the present moment, especially when they engaged the younger generation who see themselves as part of the "rainbow nation" and easily get along. However, some students admitted that the older generation expressed a memory of a Coloured versus African conflict. There were also students who said some of their interviewees traced it back to apartheid where the different black groups (African, Coloured and Indian) were placed in an apartheid hierarchy.

One African student then noted that she lived in a Coloured area where African people were of a higher income bracket than Coloured people. From her perspective this challenged the apartheid narrative of black being equated with poverty. I attempted to explain how this is a classic example of apartheid still affecting us in the post-apartheid era - an example of how class and race were conflated during apartheid. I explained that middle-class Africans lived in poor or working-class Indian, Coloured and white areas as those areas were perceived to be better than any African area, including middle-class or upper middle-class African areas in African townships. An African person moving into a former Coloured-only neighbourhood would be seen as moving up in the world, even if the Coloured residents they found there were of a lower income bracket. The property price differences between Indian, Coloured and African neighbourhoods also 
showed this class and race conflation with properties in African neighbourhoods being the cheapest of the three.

My lecture did not go well with the students. Students accused me of suggesting that Coloureds cannot be poor because of the advantages they received during apartheid. Students said that they and their families have always been and continue to be poor even though they are Coloured and it's therefore not fair to claim that they have or have had any advantage or privilege from being Coloured in South Africa during or after apartheid. I attempted to show some of the differentiated experiences of apartheid across black groups by asking students about the level of education their parents had and their current lives. A quick polling among students showed that parents of the same age had different life trajectories based on whether they were African or Coloured. A large number of Coloured students in the class had parents with only matric or no matric who were living middle-class lives while the parents of African students in the majority needed at least one or two university degrees in order to lead lives of the same or similar standard.

The discussion became heated and led to Coloured students in particular expressing feelings of being misrepresented, having their parents' hard work undermined and insulted. They accused me of suggesting that Coloured students who were poor had only themselves to blame because they didn't use their privileges during apartheid. The whole class including me was uncomfortable and unsettled. There was a clear rupture and frustration all around. I felt misunderstood and students felt misunderstood. I was left wondering - what went wrong? What did I say that offended students so much? Was it what we spoke about or the type of language I used that led to the misunderstanding? Where did students' defensiveness come from? Why was it so difficult to teach this history of differentiated apartheid oppression?

\section{NANCY FRASER'S PARTICIPATORY PARITY FOR SOCIAL JUSTICE MODEL}

Fraser's work on identity politics $(1999,2013)$ is of particular interest for this study which aims to explore the politics of identity and the complications that are presented in the South African context, where, under the apartheid regime, privilege and oppression were not clearly demarcated, but privilege was assigned on a continuum depending on the colour of your skin and the straightness of your hair. ${ }^{6}$ Fraser's work is useful

6 The 1950 Population Registration Act required that each inhabitant of South Africa be classified and registered in accordance with his or her racial characteristics as part of the system of apartheid. Since a person's racial heritage was not always clear, during apartheid years a variety of tests were devised to help authorities classify people. One such test was the "Pencil Test." The pencil test involved sliding a pencil or pen in the hair of a person whose racial group was uncertain. If the pencil fell to the floor, the person "passed" and was considered white. If it stuck, the person's hair was considered too kinky to be white and the person was registered as Coloured. 
for analysing this complexity because rather than assigning privilege to a particular race, gender or class, it is able to delve into the nuances of intersectionality and the complexities and relativities of privilege.

This paper was part of a larger body of work looking into student experiences regarding participatory parity in different disciplinary and higher education contexts in the Western Cape. Nancy Fraser's concept of participatory parity (1999, 2003, 2008, 2013) was useful to this paper and the bigger project because she highlights unequal access to resources by citizens and its impact. The reflection above exemplifies the importance for students to understand how unequal access was created by the system of apartheid and how this continues to impact South African society today in general, and voting patterns in particular. In her 1999 chapter "Social Justice in the Age of Identity Politics: Redistribution, Recognition, and Participation," and in her book Fortunes of Feminism (2013), Fraser challenges the widely held dissociation or even polarisation of two social justice claims: economic distribution and cultural recognition. Rather than pitting one against the other, by offering an integrated framework that would address both issues of redistribution and recognition, she (Fraser 1999) argues that both are necessary requirements for a socially just society. She uses the example of gender, which can be seen as linked to economic oppression, through for example gendered work patterns and salary structures and gendered divisions of paid and unpaid labour and care. At the same time gender is linked to issues around cultural recognition and status subordination, because of the hegemony of patriarchy, leading, for example, to gender-based violence (Fraser 1999). Therefore, moving towards social justice in this instance would involve applying a two-dimensional theoretical framework based on both economic redistribution and cultural recognition. Fraser later introduces a third element: political representation, i.e. the ability to participate in political decision making (2008). A similar argument can be made for other axes of subordination, such as race, class or sexuality. While she concedes that some axes will lean more towards the need for economic redistribution, such as class, or more towards the need for cultural recognition, such as sexuality, all need to be addressed across all three dimensions to achieve participatory parity.

The concepts of maldistribution, misrecognition and misrepresentation are crucial to understand apartheid-generated differentiated experiences of oppression. Apartheid and its history of differentiated oppression resulted in a hierarchy that placed Coloured people above African people, not only economically and politically but also socially (Adhikari 2004, 2016; Crankshaw 2012; Erasmus 2001). This hierarchy still exists in South Africa and in South African classrooms. As shown in the reflection above, Fraser's $(1999,2003,2008,2013)$ participatory parity is at work, in particular regarding the interrelatedness of redistribution, recognition and representation, when discussing voting patterns in the Western Cape. The right to vote needs to be accompanied by a critical understanding of voting patterns and their identity bias. Her theory provides a glimpse of the kinds of frameworks or analyses that South Africans can use to highlight 
both oppression and points of privilege and to seek ways to remedy these in a way that is not divisive for learners from African and Coloured communities.

\section{REFLECTION 2: THE CONFLICT CONTINUES...}

Asanda: I heard that some of the students' parents had complained to my course convenor. Most complaints were in written form but some parents came in person accusing me of dividing the class along racial and ethnic lines. They demanded that action against me should be taken for racialising and dividing students. I was left wondering-what was I teaching that was so divisive? I felt real discomfort about the lecture and how it ended as well as real fear for my career. Had I overstepped the mark? Had I gone overboard in my attempt to show and explain differentiated oppression under apartheid? I wondered if I should apologise to the offended students and stay away from this difficult knowledge in the future. Or could I find another way of illustrating my point to help students understand the lesson I sought to teach in the first place?

With hindsight I realised that the exercise failed because the students and I did not start from the same base of knowledge. I spoke to some students who expressed that they did not understand the term privilege in the sociological sense but understood it in the commonly held understanding of the term - that it refers to someone with wealth and means. So to be privileged would mean to be wealthy. Might this have been the reason for working-class Coloured students to be so offended-because they felt I was saying they were wealthy when their lived realities were far from this?

I also realised that I had naively assumed a priori knowledge of how apartheid implemented separate policies and laws in the different communities of Africans, Coloureds and Indians. Many students had not been aware of the existence of differentiated oppression during apartheid and those who were, were not aware of the extent of the differentiation. Most importantly I had assumed that students knew how to talk about these difficult issues, without falling into the usual traps of defensiveness and denial. It was new and difficult knowledge and it made them afraid because it challenged what they knew and had been taught by their parents, schools and society.

I met with the course convener and we discussed a way forward to address students and the complaints from parents. We agreed that there needed to be another lecture that focused on facts and figures which illustrated what I was attempting to teach previously. In this second lecture, I provided students with facts and figures like the government's spending on education, which at the peak of apartheid meant that schools serving white students had more than 10 times the funding per pupil than the schools serving African students (Fiske and Ladd 2005). Spending was also differentiated between people of colour: in 1982 the figure of spending for schooling amounted to R1211 for a white child, R771 for an Indian child, R498 for a Coloured child and R146 for an African child (Equal Education 2011). But still I felt I wasn't getting through to my students. The defensiveness and discomfort remained in the classroom. Students did not answer 
questions posed in the lecture as easily as before. My classes are usually interactive with lots of student discussions and debate around the topic of the day, but this time I was met with silence and little motivation for engagement. Where students before were chatty and engaged now I encountered silence and contempt. Some of the students who were upset by the last lecture were also visibly absent from class.

\section{THE INTERSECTIONALITY OF PRIVILEGE}

Intersectionality is a feminist term first used by Kimberle Crenshaw (1989) which calls for the recognition of multiple identities - an understanding of women as complex beings with multiple identities. It is the recognition that women's feminism is affected by their social position through their race, colour, age, social class, ethnicity, culture, etc. (Samuels 2008, 5). Intersectionality theory comes from the writings of women of colour in the 1960s and 1970s and beyond, including feminist scholars like hooks (1994, 1995, 2000a, 2000b) and Yuval-Davis (2006, 2011). According to Samuels $(2008,5)$ :

Intersectionality theory avoids essentialising a single analytical category of identity by attending to other interlocking categories. In a non-traditional way, intersectionality enables us to stretch our thinking about gender and feminism to include the impact of context and to pay attention to interlocking oppressions and privileges across various contexts.

It is important to say that intersectionality is more than just "layers of identity piled on top of each other," rather it is a complex web of identities that meet (Pompper 2014), constituting each other (Yuval-Davis 2006).

Intersectionality in feminism helped us understand differentiated oppression and the importance of acknowledging common oppression (patriarchy) whilst recognising the different implications it has for different races and its resultant strands of feminism, i.e. white feminism and black feminism. Intersectionality was useful for us in solving the conflict encountered in class because it allowed us to interrogate differentiated oppression under apartheid by acknowledging that there was oppression against all black people whilst also recognising that the oppression and its depth was dependent on whether the black person was Indian, Coloured or African. hooks $(1994,88)$ argues that identity politics are necessary for oppressed and exploited groups to have "a standpoint from which to critique dominant structures, a position that gives purpose and meaning to struggle." Intersectionality theory allows for the acknowledgement of commonality between Coloured and African communities - which is important for the larger political project of fighting white supremacy — while at the same time interrogating the differences or differentiated experiences of the oppression of people of colour.

\section{REFLECTION 3: INTRODUCING THE PRIVILEGE WALK}

Asanda: As it had become clear that part of the conflict stemmed from the lack of understanding of the sociological definition of privilege, I felt that I had to find a way to 
help students understand the term in its sociological definition. I also had to help them visualise differentiated oppression or intersectionality as talking about it had proved a futile exercise. I had to find a way to engage students on this difficult knowledge and to help them overcome their defensiveness, allowing them to stay open to each other's differentiated experiences of oppression rather than pitching their individual pain against each other. In a discussion with my colleague - Daniela Gachago - about my frustrations we came up with the idea of using the Privilege Walk in order to demonstrate systemic privilege and its meaning and also to show the intersectionality of privilege and how it plays out in everyday life. Maybe if students set up South Africa's complex social grid with their bodies, it would be harder to deny?

\section{DEBUNKING THE NOTION OF PRIVILEGE}

To debunk students' notion of privilege we had to develop a way to visualise privilege and intersectionality, beyond mere discussion, beyond the "discursive" (Massumi 2002). Adopting the Privilege Walk we aimed at facilitating an embodied and affective understanding of the socio-historical roots of privilege. Framed by critical pedagogy (Freire 2005; hooks 1994) and a focus on the intersectionality of privilege, this activity forces students to acknowledge their position in a privilege grid. The Privilege Walk is well known and used in social justice and diversity education. It is based on statements drawn from anti-racism educator and activist Peggy McIntosh's "White Privilege Checklist" (1992). McIntosh created this list to help white people acknowledge their privilege, which is often "invisible" (in similar ways that male privilege is unacknowledged in our society). As a white woman, she explains, "I have come to see white privilege as an invisible package of unearned assets which I can count on cashing in each day, but about which I was 'meant' to remain oblivious" (McIntosh 1992, 30).

Participants in the Privilege Walk are positioned in a social grid that poignantly represents the current state of our society. The statements in this exercise usually result in white males positioned at the front of the grid, while African females are at the back of the grid. Statements do not only focus on race but are intersectional in that they focus on race, gender, class, sexuality, age, religion, etc. ${ }^{7}$ This allows students to see privilege as more than financial advantage and more than just white privilege. It is a powerful activity that creates space for interesting conversations about the legacy of apartheid and how our society still values whiteness, masculinity and heteronormativity. Often facilitators follow established lesson plans, ${ }^{8}$ but many adapt the statements to suit their particular background.

7 See for example http://www.albany.edu/ssw/efc/pdf/Module\%205_1_Privilege\%20Walk\%20 Activity.pdf

8 See for example https://peacelearner.org/2016/03/14/privilege-walk-lesson-plan/ 


\section{SNAPSHOT 1: THE PRIVILEGE WALK}

Daniela: On the day of the Privilege Walk I feel nervous. I wonder how students will react. I have never met them before, have not done the exercise with students before. What if it backfires - making it more difficult for Asanda, leading to more complaints by parents?

I enter the class and first talk about my own experience of being white in South Africa, how I never felt white before coming to Cape Town and how I slowly have started understanding what white privilege means, the "invisible" knapsack that Peggy McIntosh talks about. I have a feeling that students listen more to me because of my whiteness; they look quite surprised that a white person can talk so openly about her white privilege. I feel them opening up and some of the previous tension dissipating. But the question of privilege remains difficult. When students are asked about what privilege means to them they refer to the monetary aspects of privilege, like a fancy car in their neighbour's garage or talk about their experiences of growing up poor and without privilege.

I introduce the Privilege Walk. We move the desks to the side of the room and I give students the usual warnings: to only respond to questions/statements if they feel they want to, to tell me when they are uncomfortable, etc. Students line up in the centre of the room. Then I read out the statements. We start with the easy ones: If you are a man, take one step forward. If English is your first language, take a step forward. The line already starts spreading out. Students laugh. The atmosphere is still light, until the more difficult statements. If you feel safe walking at night, take a step forward. If you were ever made fun of or bullied for something you could not change or was beyond your control, take one step back. If you have ever been a victim of violence, take a step back. Students become quiet. Move back and forth. If there was ever substance abuse in your household, take one step back. If you were ever uncomfortable about a joke related to your race, religion, ethnicity, gender, disability, or sexual orientation but felt unsafe to confront the situation, take one step back. The grid becomes clearer and clearer. The one white guy is right at the front, on his own, Coloured men close behind him, African men next, Coloured women in the middle and African women at the back. Some of the African women are so far back, they can't go any further, hitting the wall. After I am done with my questions I ask students to just quietly look around them: taking in where they stand, taking in where their peers stand. Closing their eyes. Just sensing how it makes them feel where they stand. And then we start to debrief.

Across all positions there are students who express surprise at their positioning but also a sense of recognition for finally being able to represent what they have always felt. A Coloured male shows surprise that he is so far ahead. A Coloured female expresses her shock at being so far back. The only white student tells us he feels uncomfortable but not surprised to be at the front. An understanding of intersectionality emerges: some African students reflect on how they do not have racial privilege for example but had "accent privilege" because they went to former whites-only schools and spoke in a way that instantly advantaged them over other African people who spoke with a "normal" 
African accent. Others mention their male and heterosexual privilege which they were not previously aware of. I am concerned about the students at the back. How do they feel? One of the African girls tells me she woke up quite happy this morning but now she feels depressed. But there is also a sense of solidarity between the women at the back and a sense of acceptance, a recognition that this is just how their lives are. Finally out in the open. I finish the lecture with a quick summary of what we did emphasising the systemic nature and the intersectionality of the exercise, and of privilege per se. Students quietly leave the room.

\section{EMBODIED AND AFFECTIVE LEARNING}

The Privilege Walk is seen as a useful embodied activity for students to create a visual representation of their social positioning. Critical race and gender theorists from BakerFletcher (1996) to bell hooks (1994, 2000a, 2000b), argue that "the body is the primary site and surface of race and representation" (Baker-Fletcher in Jackson 2006, 1). This activity also allows participants to see "misrecognition as status subordination whose locus is social relations, not individual psychology" (Fraser 1999, 35). It allows students to see oppression and privilege as something they or their parents are not personally responsible for. Through the exercise students can start to show an understanding that the meritocracy discourse (as long as you work hard enough) can be detrimental to their understanding of self and positionality. As Fraser $(1999,35)$ explains:

It is rather to be denied the status of a full partner in social interaction and prevented from participating as a peer in social life as a consequence of institutionalized patterns of cultural value that constitute one as comparatively unworthy of respect or esteem. When such patterns of disrespect and disesteem are institutionalized, they impede parity of participation, just as surely as do distributive inequities.

The Privilege Walk as an embodied experience visualises systemic privilege and breaks the silence on how systems continue to favour some in lieu of others, in ways that lectures or discussions alone were not able to. McIntosh $(1992,35)$ states that in order to "redesign social systems we need first to acknowledge their colossal unseen dimensions. The silences and denials surrounding privilege are the key political tool here." The exercise made it possible not only to see that there needs to be a deconstruction and challenge to the notion of meritocracy, as many have certain positions in society due to unearned privileges, but that we are also all part of and implicated in an oppressive system that penalises those who are excluded from the centre or dominant group.

\section{REFLECTION 4: AFTER THE PRIVILEGE WALK}

Daniela: Reflecting back on the Privilege Walk with students I felt it allowed students to develop a more nuanced understanding of privilege. In the debriefing after the activity the African students told us that the exercise confirmed what they already intrinsically knew 
but what was usually silenced in class and society. The Coloured and white students on the other hand felt that they understood the intersectionality of privilege better. But we were still uncomfortable - there was a nagging question for us: yes, learning had taken place but at whose and what cost?

I was particularly concerned about the African students. I couldn't get that image of the African women hitting the wall out of my mind. We confirmed their social standing but did not do anything to help show them alternative ways of being nor did we show the other students who had race, class and gender privilege what a new world in which unearned privilege was removed would look like. We felt that the class had learnt something from the Privilege Walk - something we had failed to teach them through engagement with literature or through political conversations. However, we also knew that the Privilege Walk in its original format was incomplete in its analysis. It was important to us that students should not feel like they are stuck in the grid but are made aware that there is potential for change if we as society change our value structures. After reflecting on ways to bring back parity to the exercise we decided we would have to develop a second part to the exercise where we asked students to come up with their own statements that promoted and valued the categories of identity that are usually undervalued and marginalised by society, such as womanhood and blackness.

\section{CHALLENGING THE PRIVILEGE WALK}

The Privilege Walk has been critiqued for a variety of reasons, including the ethics of potentially disclosing factors of one's identity one is not comfortable to disclose (Bridges 2012). As a result there are a variety of iterations of the Privilege Walk, responding to these critiques. One variation, for example, asks participants to answer the questions/ statements on their own and calculate a privilege score which they anonymously submit to be pinned on a chart by the facilitator. ${ }^{9}$

One of the main points of discomfort for us is encapsulated by the questions at whose cost does the learning take place and who learns? While the Privilege Walk powerfully visualises the inequality of today's society it is traumatising for those at the back of the grid; as Torres (2015) puts it: "Essentially, when you're a PoC or from another oppressed background, you inevitably end up in the back. And you know that you will." This is a common critique within critical pedagogy, where the burden of teaching is often held by the oppressed group, potentially triggering and re-traumatising the already traumatised; as Ellsworth $(1989,317)$ reflects: "[white] students should have shared the burden of educating themselves about the consequences of their White-Skin privilege," rather than expecting their black peers to explain privilege and oppression to them.

The Privilege Walk exercise in its original format cements current social positions without allowing for change or disruption of the social system we are re-creating. It is

9 See for example http://timeandplace.ubc.ca/user-guide/theme-ii/activity-a-variation-2/ 
a visualisation of the status quo rather than an exercise in envisioning an alternative future. It focuses on a student's identity, often essentialising it, despite its emphasis on intersectionality, rather than seeing identity as constantly changing and becoming. The privilege circle, ${ }^{10}$ which rather than a line has participants stand in a circle, with the ones usually most disadvantaged moving into the centre of the circle, is one example of challenging power dynamics in the grid.

We argue, however, this still doesn't go far enough. Our aim is to challenge the grid itself. Fraser (2003) warns that affirmative approaches in social justice education may highlight some of the injustices encountered in the classroom but do not challenge the system itself. In our case we see the traditional Privilege Walk as an affirmative pedagogy as it highlights and breaks the silence around issues of systemic privilege. Transformative approaches in social justice education, however, would involve practices that address the root causes of maldistribution, misrecognition and exclusion/ misrepresentation, therefore changing the grid itself is key.

Here, the work on affect by Brian Massumi (2002) resonated with us and proved useful in moving us and our student bodies out of their current social positioning. Massumi $(2002,1)$ argues that bodies move and feel, "both at the same time. It moves as it feels, and it feels as it moves." As such, bodies and movement become central to acts of everyday practices of resistance and social change. He traces how bodies are positioned and as such defined in specific "sites" on a grid, based on culturally constructed binaries such as male/female, black/white, gay/straight and so on. He asks important questions about this grid and the possibilities of changing positions on the grid, but also changing the grid itself: "How does a body perform its way out of a definitional framework that is not only responsible for its very 'construction,' but seems to pre-script every possible signifying and counter-signifying move as a selection from a repertoire of possible permutations on a limited set of predetermined terms? How can the grid itself change?" (Massumi 2003, 3).

This is of particular interest for our study where our students move into a specific grid and that movement, their positioning in this grid, does something to them, impacts on their being, their feelings and their knowing. What follows then is that when our students move into a different grid, a different positioning, they might be, feel and think differently. Following Massumi (2002) we tried to challenge the cementing of social positionings - the pinning of bodies onto a grid defined by a patriarchal, white supremacist and heterosexual society. Here again we go beyond the discursive, further into the realm of sensation, affective and bodily learning.

\section{SNAPSHOT 2: DREAMING UP A NEW GRID}

Asanda and Daniela: As part of a conference for student leaders at the University of Stellenbosch we were invited to engage with students on critical tools for engagement.

10 See for example https://indypendent.org/2013/08/17/take-privilege-walk 
We decide to take up this opportunity to try and develop our ideas around the Privilege Walk further. We introduce the Privilege Walk and run students through the traditional set of statements. As a follow up activity however we ask students to - in groupscome up with statements that might challenge the existing grid. We give students a few minutes to brainstorm in their small groups. The room is buzzing. The noise levels increase. We then ask students to share some of the statements they have developed. Students tell us that they struggled to formulate these statements. Eventually they start sharing some of their ideas and a new grid emerges, affirming Africanness, womanhood, but also courage, openness and consciousness.

Examples of statements include:

- If you can speak other South African languages beyond English or Afrikaans take a step forward.

- If you grew up in a tightly knit community where everyone contributed to your development take a step forward.

- If you dressed up this morning the way you wanted to be dressed without thinking about societal norms take a step forward.

- If you sought information about social issues outside of your own lived experience in the recent months take a step forward.

- If you are male and can work under or with women take a step forward.

- If you can reduce your privilege for somebody else step forward.

We feel a strong sense of relief in the room. Something has shifted, changed. When we ask them what just happened, students seem to struggle to put it in words. They look at each other. It's unsettling and new to see all these women in the front. Finally one of the white male students, now at the back (but nowhere near the very back as the students were in the first grid), tells us how good it feels to shift positions - how much better he feels at the back than at the front. The women in the front smile and one of the black women tells us that it's the first time she feels good standing next to a white woman. The group starts laughing. But she also adds that it feels strange, like she doesn't belong, to stand at the front for the first time in her life. The energy in the room has changed and the ensuing conversations are lively and animated. Many express that we had visualised and explained the need for Affirmative Action and Black Economic Empowerment for example, in a way that ordinary conversations previously failed to do.

These students created a new social grid affirming different values and identities. We were surprised that many of the students' statements referred less to social locations and more to cultural practices and values. Yuval-Davis (2006) argues that while belonging and identity are linked to social locations, such as race and gender, we also identify by cultural practices and in particular ethical and political values, such as openness and 
generosity, which were the ones that were most accessible to students to create a new grid.

It is important to note that if these new questions had done nothing but turn the first grid around, our exercise would have failed. Massumi warns that in that case, "[ $t]$ he very notion of movement as qualitative transformation is lacking. There is 'displacement,' but no transformation, as if the body simply leaps from one definition to the next" $(2002,3)$. What is needed is the envisioning of a completely new grid, based on new social locations, practices and values that would affirm difference and becoming. What the new grid showed is that although other students found themselves at the front, in general students were not as spread out as before, but stood much closer together.

\section{CONCLUSION}

In this paper we reflected on a pedagogical intervention that we introduced last year across a range of South African classrooms and workshops, and the tensions that we experienced when engaging with difficult knowledges such as identity politics and privilege. We used the Privilege Walk as an attempt to help students understand not only intellectually, but affectively - with and through their bodies - the systemic and historical roots of privilege. It allowed us to delve into the grey areas of racial theory and intersectionality and develop a more complete understanding of differentiated oppression and privilege and students' lived experience.

In a country like South Africa, it also helped us and our students understand the necessity of understanding historical events in order to make sense of the present. Concepts like Fraser's notion of maldistribution allowed us to understand how racial, gender and class discriminations inherent in the apartheid system still affect us to this day. Intersectionality theory provided an explanation and analysis of differentiated oppression and the need to acknowledge both commonalities and difference when dealing with patriarchy or white supremacy. In the same way that black feminism and white feminism allow for an acknowledgement of the differentiated experience of oppression by patriarchy, we can analyse the differentiated experiences of oppression across one race. Conducting the Privilege Walk in a mostly black class allowed us to explore the complexities of privilege across black people in South Africa, which led to a nuanced understanding of the apartheid system and its impact on black people today.

This autoethnographic study gave us the space to reflect on our journey of both engaging in and disrupting identity politics in a South African classroom. The Privilege Walk allowed students to see the complexity and systemic nature of privilege and its impact on students' lives by foregrounding its socio-political rather than personal dimensions. This helped overcome some of the defensiveness that usually accompanies difficult conversations in the classroom. It also recognised the lived experiences of some of our most vulnerable students. By further developing the Privilege Walk to affirm difference and envision a new social grid, based on alternative values, where 
students shifted positions in often dramatic ways, it was our hope to further affirm these students - even if only for the few moments in which they did not, as usual, stand at the back. Those coming into difficult knowledge for the first time were given tools through the new grid and experienced their own power to change the status quo, while acknowledging that race, gender and class do matter and continue to determine their own and their peers' life trajectories.

Although systems are hard to change, such interventions can help students to experience and feel intersectionality, the detrimental and positive power of language and its ability to instantly include and exclude, creating small acts of "resistance" or "subversion" and keeping alive the possibility of systemic change (Massumi 2002). We believe it is important that positionality followed movement: it is the process of moving, of our students changing positions that is crucial in this activity; as Massumi $(2002,8)$ states: "positionality is an emergent quality of movement." Students with and through their moving bodies started the work of unlearning previously ingrained social habits and ways of feeling, thinking and being towards the recognition and affirmation of difference rather than fearing it as a divisive force that must not be spoken of. In their bodies' movements through different grids, we hope that they experienced fluidity and becoming, rather than being, seeing and experiencing identity as something fixed. Using embodied and affective learning, the exercise helped students to overcome the defensiveness that often disrupts attempts to engage with difficult knowledges across racial, gender and class divides and understand each other better.

\section{ACKNOWLEDGEMENT}

We would like to thank our students who allowed us to engage in difficult conversations. Furthermore, we would like to thank the reviewers of this paper whose thoughtful feedback greatly improved this article.

\section{REFERENCES}

Adhikari, M. 2004. “'Not BlackEnough': Changing Expressions of Coloured Identity in Post-Apartheid South Africa.” South African Historical Journal 51: 167-78. https://doi.org/10.1080/02582470409464835

Adhikari, M. 2006. "Hope, Fear, Shame, Frustration: Continuity and Change in the Expression of Coloured Identity in White Supremacist South Africa, 1910-1994." Journal of Southern African Studies 32 (3): 464-87. https://doi.org/10.1080/03057070600829542

Baines, G. 1998. "The Rainbow Nation? Identity and Nation Building in Post-Apartheid South Africa." Mots Pluriels 7: 1-12. http://www.arts.uwa.edu.au/MotsPluriels/MP798gb.html (accessed August 15, 2017).

Biko, S. 1978. "Black Consciousness and the Quest for a True Humanity." Ufahamu: A Journal of African Studies 8 (3): 10-20. 
Bridges, T. 2012. “Teaching Privilege without Perpetuating Privilege.” Inequality by (Interior) Design, August 31. https://inequalitybyinteriordesign.wordpress.com/2012/08/31/teaching-privilege-withoutperpetuating-privilege/ (accessed December 19, 2016).

Britzman, D. P. 2000. "Teacher Education in the Confusion of Our Times." Journal of Teacher Education 51 (3): 200-205. https://doi.org/10.1177/0022487100051003007

Crankshaw, O. 2012. "Deindustrialization, Professionalization and Racial Inequality in Cape Town." Urban Affairs Review 48 (6): 836-62. https://doi.org/10.1177/1078087412451427

Crenshaw, K. 1989. "Demarginalizing the Intersection of Race and Sex: A Black Feminist Critique of Antidiscrimination Doctrine, Feminist Theory and Antiracist Politics." University of Chicago Legal Forum 140: 139-67.

Ellis, C. 2004. The Ethnographic I: A Methodological Novel about Autoethnography. Walnut Creek: Altamira Press.

Ellsworth, E. 1989. "Why Doesn't This Feel Empowering? Working through the Repressive Myths of Critical Pedagogy." Harvard Educational Review 59 (3): 297-325. https://doi.org/10.17763/ haer.59.3.058342114k266250

Equal Education. 2011. "Unequal Schools. Unequal Outcomes. Youth Group Fact Sheet.” http:// equaleducation.org.za/node/603 (accessed May 11, 2016).

Erasmus, Z. 2001. Coloured by History, Shaped by Place. Cape Town: Kwela Books.

Erasmus, Z., and E. Pieterse. 1999. "Conceptualising Coloured Identities in the Western Cape Province of South Africa." In National Identity and Democracy in Africa, edited by M. Palmberg, 167-87. Cape Town: Human Sciences Research Council.

Fiske, E. B., and H. F. Ladd. 2005. Racial Equity in Education: How Far Has South Africa Come? Working Paper Series SAN05-03. North Carolina: Duke University.

Fraser, N. 1999. "Social Justice in the Age of Identity Politics: Redistribution, Recognition, and Participation." In Culture and Economy after the Cultural Turn, edited by L. Ray and A. Sayer, 25-52. London: Sage. https://doi.org/10.4135/9781446218112.n2

Fraser, N. 2003. "Social Justice in the Age of Identity Politics: Redistribution, Recognition and Participation." In Redistribution or Recognition? A Political-Philosophical Exchange, edited by N. Fraser and A. Honneth, 7-109. London: Verso.

Fraser, N. 2008. Scales of Justice: Reimagining Political Space in a Globalising World. Polity Press: Cambridge.

Fraser, N. 2013. Fortunes of Feminism. London: Verso.

Freire, P. 2005. Pedagogy of the Oppressed. New York: Continuum.

Harvey, E. 2016. "Why the Coloured Vote Has Been So Elusive for the ANC." Mail\&Guardian, April 21. https://mg.co.za/article/2016-04-21-why-the-coloured-vote-has-been-so-elusive-for-the-anc-2 (accessed December 19, 2016). 
hooks, b. 1994. Teaching to Transgress: Education as the Practice to Freedom. New York: Routledge.

hooks, b. 2000a. Feminist Theory: From Margin to Center. London: Pluto Press.

hooks, b. 2000b. Feminism Is for Everybody: Passionate Politics. Cambridge, MA: South End Press.

Iseke-Barnes, J. M. 2008. "Pedagogies for Decolonizing." Canadian Journal of Native Education 31 (1): $123-48$.

Jackson. R. L. 2006. Scripting the Black Masculine Body: Identity, Discourse, and Racial Politics in Popular Media. New York: Suny Press.

Jansen, J. 2009. Knowledge in the Blood: Confronting Race and Apartheid Past. Stanford: Stanford University Press.

Kanu, Y. 2011. Integrating Aboriginal Perspectives into the School Curriculum: Purposes, Possibilities, and Challenges. Toronto: University of Toronto Press.

Leonardo, Z., and R. K. Porter. 2010. "Pedagogy of Fear: Toward a Fanonian Theory of 'Safety' in Race Dialogue." Race Ethnicity and Education 13 (2): 139-57. https://doi.org/10.1080/13613324.2010.4 82898

Mangcu, X., ed. 2015. The Colour of Our Future. Does Race Matter in Post-Apartheid South Africa? Johannesburg: Wits University Press.

Massumi, B. 2002. Parables for the Virtual: Movement, Affect, Sensation. Durham: Duke University Press. https://doi.org/10.1215/9780822383574

Matandela, M. 2015. "Rhodes Must Fall: How Black Women Claimed Their Place." Mail\&Guardian, March 30. https://mg.co.za/article/2015-03-30-rhodes-must-fall-how-black-women-claimed-theirplace (accessed August 15, 2017).

McKaiser, E. 2014. Could I Vote DA? Johannesburg: Bookstorm.

McIntosh, P. 1992. "White Privilege: Unpacking the Invisible Knapsack." In Multiculturalism, edited by A. M. Filor, 30-36. New York: New York State Council of Educational Associations. http://files.eric. ed.gov/fulltext/ED355141.pdf\#page=43 (accessed December 19, 2016).

Ndlovu-Gatsheni, S. 2013. Coloniality of Power in Postcolonial Africa: Myths of Decolonization. Dakar: CODESRIA.

Pompper, D. 2014. Practical and Theoretical Implications of Successfully Doing Difference in Organizations. Vol.1 of International Perspectives on Equality, Diversity and Inclusion. Bingley: Emerald Group Publishing. https://doi.org/10.1108/S2051-2333(2014)1

Samuels, G. M., and F. Ross-Sheriff. 2008. "Identity, Oppression, and Power: Feminisms and Intersectionality Theory." Affilia: Journal of Women and Social Work 23 (1): 5-9. https://doi. org/10.1177/0886109907310475 
Sherriff, L. 2015. "White Students Form Human Shield to Protect Black \#FeesMustFall Protesters from South African Police." Huffpost, October 22. http://www.huffingtonpost.co.za/entry/white-studentsform-human-shield-protect-black-protesters-south-african-police_n_8356054 (accessed August 14, 2017).

Thomas, C. G. 2004. "The Right to Housing in Post-Apartheid South Africa: Why Some of the Nicest Plans Can Sometimes Go Wrong." Paper presented at the Adequate and Affordable Housing for All Conference, Centre for Urban and Community Studies, University of Toronto, Toronto, June 24-27. http://www.urbancentre.utoronto.ca/pdfs/housingconference/Thomas_Right_to_Housing_Sou.pdf (accessed December 19, 2016).

Torres, C. 2015. "Why 'the Privilege Line' is a Frustratingly Unfinished Exercise (and How to Make It Better...Maybe)." Christina Torres, July 9. https://christinatorres.org/2015/07/09/why-the-privilegeline-is-a-frustratingly-unfinished-exercise/ (accessed December 19, 2016).

Yuval-Davis, N. 2006. "Belonging and the Politics of Belonging." Patterns of Prejudice 40 (3): 197-214. https://doi.org/10.1080/00313220600769331

Zembylas, M. 2011. The Politics of Trauma in Education. New York: Palgrave Macmillan.

Zembylas, M. 2013. "The 'Crisis of Pity’ and the Radicalization of Solidarity: Toward Critical Pedagogies of Compassion.” Educational Studies 49 (6): 504-21. https://doi.org/10.1080/00131946.2013.844148

Zembylas, M. 2014. “Theorizing 'Difficult Knowledge' in the Aftermath of the 'Affective Turn': Implications for Curriculum and Pedagogy in Handling Traumatic Representations." Curriculum Inquiry 44 (3): 390-412. https://doi.org/10.1111/curi.12051 